\title{
Criminal Safeguards and the Punitive Damages Defendant
}

\author{
The award of punitive, or exemplary, damages, with its peculiar goal \\ of civil punishment, ${ }^{1}$ has long been regarded as a legal anomaly. ${ }^{2} \mathrm{~A}$
}

1 Punitive damages are generally defined as "those given in enhancement of compensatory damages on account of the wanton, malicious or reckless character of the acts complained of." Great Atlantic \& Pacific Tea Co. v. Smith, 281 Ky. 583, 600, 136 S.W.2d 759, 768 (1939). See generally MCCormick, DAMAGEs $\$ 81$ (1935). As to the availability of punitive damages in contract actions, see ibid.; Note, Exemplary Damages in the Law of Torts, 70 HARv. L. Rev. 517, 531-33 (1957). Apparently, these damages developed in eighteenth century English courts seeking to justify damage awards in excess of plaintiff's tangible harm, at a time when recovery for intangibles such as pain and suffering was not allowed. See Fay v. Parker, 53 N.H. 342 (1873); I SEDGwick, Measure of Damages $\$ \$ 348-50$ (9th ed. 1912); Ghiardi, Should Punitive Damages Be Abolished?-A Statement for the Affirmative, [1964-1965] ABA Section of Insurance, Negligence and Compensation Law Prockedings 282, 283, 286. Thus, judges upheld high verdicts by referring to the plaintiff's wounded dignity, mental suffering, and the like, where defendant's conduct was marked by malice, recklessness, or other outrageousness. Ibid. Today, however, mental anguish and other formerly unrecognized elements of damage are included in compensatory damages, and most jurisdictions now justify punitive damages as a means of punishing the defendant and of deterring him and others from committing like offenses in the future. See Washington Gaslight Co. v. Lansden, 172 U.S. 534 (1899); Eshelman v. Rawalt, 298 Ill. 192, 131 N.E. 675 (1921); Morris v. MacNab, 25 N.J. 271, 135 A.2d 657 (1957); Cosgriff Bros. v. Miller, 10 Wyo. 190, 68 Pac. 206 (1902); Ghiardi, supra.

In addition to the punitive-deterrent function of punitive damages, a revenge function is said to exist. By increasing the defendant's burden of damages, the plaintiff obtains a sense of vindictive satisfaction and refrains from violent self-help. Merest v. Harvey, 5 Taunt. 442, 128 Eng. Rep. 761 (C.P. 1814); see 2 HoldsworTH, A History OF ENGLISH LAW 43-45, 50-51 (4th ed. 1936); Holmes, The Common Law 2-4, 39-42 (1881). Punitive damages may also provide a public revenge, through the jury's treatment of the offender. See Gostkowski v. Roman Catholic Church of the Sacred Hearts, 262 N.Y. 320, 324-25, 186 N.E. 798, 800 (1933); Wilkes v. Wood, Lofft 1, 19, 98 Eng. Rep. 489, 498-99 (C.P. 1768). In a few states it has been held that exemplary damages are awarded not by way of punishment, but as compensation for the greater wrong suffered; the penal effect is said to be incidental. See Doroszka v. Lavine, 111 Conn. 575, 578, 150 Atl. 692-93 (1930); Wise v. Daniel, 221 Mich. 229, 190 N.W. 746 (1922); Fay v. Parker, 53 N.H. 342 (1873).

2 See Fay v. Parker, 53 N.H. 342 (1873); Bass v. Chicago \& N. Ry., 42 Wis. 654 (1877); Prosser, TORTS $\$ 2$, at 9 (3d ed. 1964); 1 SEDGwick, op. cit. supra note 1 , § 353, at 699 (9th ed. 1912); Willis, Measure of Damages When Property is Wrongfully Taken by a Private Individual, 22 HARv. L. REv. 419 (1909). For other criticism of punitive damages, see Murphy v. Hobbs, 7 Colo. 541, 5 Pac. 119 (1884); Spokane Truck \& Dray Co. v. Hoefer, 2 Wash. 45, 25 Pac. 1072 (1891); Pegram v. Stortz, 31 W. Va. 220, 6 S.E. 485 (1888); 2 GreEnt.eAF, Evmence §§ 253, 272 (14th ed. 1883); Hale, Damages $\$ 87-88$ (2d ed. 1912); McCormick, Damages \$\$ 77-85 (1935); Morris, Punitive Damages in Tort Cases, 44 Harv. 
revival of interest in punitive damages-due in part to large libel awards such as in the celebrated New York Times case ${ }^{3}$ and to a breakdown in insurance protection against punitive damages awards ${ }^{4}$-has been accompanied by one recurring theme. Commentators, observing the similarity between the punitive-deterrent purposes of punitive damages and those of criminal sanctions, ${ }^{5}$ ask why the punitive damages defendant is not afforded the safeguards which protect the criminal defendant, such as the plaintiff's heavier burden of "proof beyond a reasonable doubt" and the protection against double jeopardy. The persistence of this apparent contradiction might be explained by the law's tendency to "domesticate" its inconsistencies-to accept contradictions simply because it has lived with them for so long. ${ }^{6}$ However, a more accurate explanation may be that this anomaly is only superficial; the lack of criminal safeguards may be the consequence of important differences between criminal punishment and its supposed civil counterpart. ${ }^{7}$

L. REv. 1173 (1931). For two recent contributions to the controversy, see Corboy, Should Punitive Damages Be Abolished?-A Statement for the Negative, [1964-1965] ABA SEction of INSURANCE, NEgligence ANd CoMpensation LAW PRockedings 292; Ghiardi, supra note 1.

Despite the controversy surrounding punitive damages, all but four states allow them: Louisiana, Vincent v. Morgan's La. \& Tex. R.R., 140 La. 1027, 74 So. 541 (1917); Massachusetts, De Marco v. Pease, 253 Mass. 499, 149 N.E. 208 (1925) (Massachusetts' wrongful death statute penal in form but remedial in effect); Burt v. Advertiser Newspaper Co., 154 Mass. 238, 28 N.E. 1 (1891); Nebraska, Boyer v. Barr, 8 Neb. 68 (1878); Washington, Spokane Truck \& Dray Co. v. Hoefer, 2 Wash. 45, 25 Pac. 1072 (1891). Nearly every state uses a statutory device closely related to exemplary damages-the sanction of double or treble civil damages. Note, supra note 1, $70 \mathrm{HARV}$. L. REv. at 518. Although the primary reason for multiple damages is said to be the encouragement of litigation, see e.g., Kink v. Combs, 28 Wis. 2d 65, 80, 135 N.W.2d 789, 798 (1965), while the major purpose of punitive damages is said to be punishment deterrence, there is a punitive effect in multiple damages and an inducement to litigation in punitive damages. Much of the criticism directed at punitive damages thus also embraces statutory multiple damages.

3 New York Times Co. v. Sullivan, 376 U.S. 254 (1964).

4 See note 8 infra. Punitive damages have also been getting increased attention from plaintiffs' attorneys. See 12 TRIAL AND TORT Trends 3-8, 57 (Belli ed. 1962); Ghiardi, supra note 1.

5 The purposes of criminal punishment axe excellently discussed in Commonwealth v. Ritter, 13 Pa. D. \& C. 285, 290-91 (Phila. County Ct. 1930) (Stern, J.). See also Barnes \& TeEters, New Horizons in Criminology 286 (3d ed. 1959), noting that the criminal penal theory is shifting its emphasis from revenge and deterrence to reformation of the offender and the protection of society. See Trop v. Dulles, 356 U.S. 86 (1958), for a test of criminal-type punishment which virtually describes the functions of punitive damages. The Court reversed a court martial conviction ordering deportation of a wartime deserter, because a disability was imposed "for the purposes of punishment-that is, to reprimand the wrongdoer, to deter others, etc." without certain fifth and sixth amendment criminal safeguards.

- Cf. Kalven, The Negro and the First Amendment 5 (1965).

7 Compare the alleged inconsistency between the liability principle of the common 


\section{The Premise of Identical Punishments}

Before considering the major criminal safeguards in detail, a basic assumption of the critics of punitive damages must be examinedthat the penal natures of punitive damages and criminal sanctions are essentially identical.

As indicated above, the purposes of criminal punishment and of punitive damages are the same: retribution, deterrence, and rehabilitation. ${ }^{8}$ However, similarity must be measured by effect as well as purpose. In this respect, criminal sanctions and punitive damages differ significantly. The effects of punishment on the defendant may be described in terms of form and severity. The particular forms of criminal punishment have been important in motivating the special safeguards accorded the criminal defendant. ${ }^{2}$ Torture and death are no longer common punishments, but imprisonment remains a familiar penal sanction. Another form of criminal punishment, more prevalent than the others, yet less widely recognized, is the stigmatization of criminal conviction, the effects of which are felt by the defendant long after any sentence has been served. ${ }^{10}$

law and that of workmen's compensation. See Blum \& Kalven, Public Law Perspectives on a Private Law Problem-Auto Compensation Plans $24-27$ (1965); Blum \& Kalven, Public Law Perspectives on a Private Law Problem-Auto Compensation Plans, 31 U. CHI. L. REv. 641, 662-65 (1964).

8 This emphasis on punishment differentiates punitive from compensatory damages, the purpose of which is to make the plaintiff whole. There is, however, a slight punitive effect accompanying ordinary liability: the defendant suffers the hardship of paying out the money needed to compensate the plaintiff. However, in many cases, there is no such loss to the defendant; the judgment serves only to restore to the plaintiff what the defendant has wrongfully gained at the plaintiff's expense. Often the ordinary damages defendant avoids hardship through insurance. Insurance, however, is not generally available to ameliorate the hardship of punitive damages; experienced insurance companies expressly exclude willful, malicious, fraudulent, and similar conduct giving rise to punitive damages from protection under their policies. See Northwestern Nat'l Cas. Co. v. McNulty, 307 F.2d 432, 445 (5th Cir. 1962). Some courts have allowed coverage for punitive damages as a matter of contract interpretation, e.g., Carroway v. Johnson, 245 S.C. 200, 139 S.E.2d 908 (1965), but courts which have considered the policy implications have concluded that insurance against punitive damages violates public policy. They note that if defendants are able to shift the punitive burden, the very purpose of punitive damages is undermined. Northwestern Nat'l Cas. Co. v. McNulty, supra at 440. Commentators have almost unanimously condemned coverage for punitive damages. See authorities cited id. at 436 n.11.

9 See, e.g., United States v. Zucker, 161 U.S. 475 (1896); Flint River Steamboat Co. v. Foster, 5 Ga. 194, 206 (1848); Comment, The Concept of Punitive Legislation and the Sixth Amendment: A New Look at Kennedy v. Mendoza-Martinez, 32 U. CHI. L. REv. 290 (1965).

10 Gardiner, The Purposes of Criminal Punishment, 21 MODERN L. REv. 117, 123 (1958): "[D]eterrence ... . works less through fear of punishment itself, than through fear of social disapprobation." 
The money judgment assessed the punitive damages defendant hardly seems comparable in effect to the criminal sanctions of death, imprisonment, and stigmatization. In theory, punitive damages have some stigmatizing effect insofar as they represent communal disapproval of the defendant's conduct. But it seems unlikely that punitive damages defendants are plagued by manifest social disapprobation as are convicted felons. ${ }^{11}$ There is no blank on a job application for listing past punitive damages judgments.

The one criminal punishment which approximates the form of punitive damages is the criminal fine. But the fine, unlike punitive damages, still carries the full weight of stigma associated with criminal conviction. Moreover, the threat of imprisonment accompanies all fines. In sentencing statutes, the fine is usually an alternative or addition to imprisonment. Since the sentence cannot be known until the trial is concluded, the defendant must be given the protections consistent with the maximum possible penalty. ${ }^{12}$

Although different in form from criminal penalties, punitive damages may approach criminal penalties in severity. A punitive damages judgment may frequently exceed a criminal fine for the same offense. For example, a recent federal decision ${ }^{13}$ upheld punitive damages of 6,500 dollars in addition to 15,000 dollars compensatory damages against a motorist who caused an accident while intoxicated. The state-imposed penalty for this conduct was a twenty-five dollar fine and revocation of the defendant's driver's license. ${ }^{14}$

11 This is particularly true because punitive damages actions are rarely given the publicity accorded a criminal prosecution.

12 While some crimes are punishable by fine alone, imprisonment threatens as well, for the defendant who fails to pay a criminal fine may be imprisoned to work off the obligation. See, e.g., IIL. REv. Stat. ch. 38, § 1-7(k) (1965); PA. Stat. ANN. tit. 18, § 4407 (1963). Civil money judgments, on the other hand, are typically enforced by garnishment, levy, or other taking of property. See Jankes, CrviL PROCEDURE \& 1.20 (1965). In some jurisdictions, though, punitive damages tort judgments are enforceable by imprisonment. Ibid.; see, e.g., McKindley v. Rising, 28 Ill. 337 (1862); Brown v. Nix, 208 S.C. 230, 37 S.E.2d 579 (1946). However, such imprisonment generally cannot be maintained unless execution on the judgment debtor's property has been returned unsatisfied. See, e.g., Martin v. Hutto, 82 S.C. 432, 64 S.E. 421 (1909); N.X. Justice Cr. ACT § 301. Since it is unlikely that a plaintiff would sue a defendant without means to pay, there is little probability that a punitive damages defendant would face imprisonment for inability to pay the judgment, particularly since most jurisdictions permit the defendant to introduce evidence of his financial status in order that the jury may adjust the punishment. See note 102 infra and accompanying text. This contrasts with the criminal fine situation, where defendants may be indigent and where attempted execution upon property may not be a prerequisite to incarceration. See, e.g., the Illinois and Pennsylvania statutes cited supra; N.Y. CODE CRrM. Proc. § 484 (Supp. 1966).

13 Brooks v. Wooton, 355 F.2d 177 (2d Cir. 1966).

14 N.Y. Times, Jan. 22, 1966, p. 31, col. 5. Compare the Illinois $\$ 1,000$ maximum fine for 
It thus appears that punitive damages, while less oppressive in form than criminal penalties, can be equally severe in degree. Form and degree cannot, however, be separated in assessing the total gravity of the consequences to the defendant. Considering this total effect, especially the stigmatization accompanying all forms of criminal punishment and the qualitative gap between imprisonment and mere economic sanctions, the consequences of criminal punishment seem more oppressive than those of a money judgment for punitive damages. Insofar as safeguards for criminal defendants are responses to peculiarly oppressive criminal punishments or represent a desire to protect defendants from the arbitrary or mistaken imposition of these punishments, they cannot be said to be vital for the defendant faced with liability for punitive damages. Yet the possibility of severe consequences may not be the sole reason for these safeguards. Therefore, it remains important to probe the relation between the purpose and consequences of punitive damages and the rationales which underlie particular safeguards. ${ }^{15}$

\section{Confrontation of Adverse Witnesses}

Over seventy-five years ago, the Colorado Supreme Court lamented that depositions could be read against the punitive damages defendant, "and thus the right of meeting adverse witnesses face to face be denied."16 The Colorado court stands alone, however, in its desire to apply the criminal defendant's constitutional right to confront adverse witnesses $^{17}$ to the punitive damages defendant. The failure of litigants to raise this issue is not surprising, since the most important adverse witness in many punitive damages cases is the plaintiff, who nearly always testifies in person at the trial. Indeed, the punitive damages defendant is accorded the right for all practical purposes, insofar as it comprehends an opportunity to identify and cross-examine hostile witnesses. ${ }^{18}$ Most jurisdictions permit civil defendants to question adverse

reckless driving which causes injury, IrL. REv. STAT. ch. 38, § 12-5 (1965), with the punitive damages possible under such circumstances.

15 This comment does not propose to evaluate the propriety of criminal safeguards for the criminal defendant, a subject now much in the legal spotlight; nor does it seek to resolve the apparent contradiction between the admonitory element of ordinary damages and the lack of special safeguards in that area of law. See generally Morris, supra note 2. The acceptance of an admonitory element in ordinary damages without special safeguards may in part explain the legal system's toleration of awarding punitive damages without these protections. This is particularly so because much of the conduct giving rise to punitive damages is not "criminal" in nature.

16 Murphy v. Hobbs, 7 Colo. 541, 544, 5 Pac. 119, 121 (1884).

17 U.S. CoNST. amend. VT: "In all criminal prosecutions, the accused shall enjoy the right ... to be confronted with the witnesses against him ..." State provisions are similar. E.g., Colo. Const. art. 2, \& 16; N.J. Const. art. 1, I 10.

18 See People v. Hume, 56 Cal. App. 2d 262, 132 P.2d 52 (1942); Coco v. State, 62 So. 2d 
deponents face to face, at the deposition stage; ${ }^{19}$ in other jurisdictions which deny that right, ${ }^{20}$ the defendant may nonetheless have the witnesses identified and cross-examined by written cross-interrogatories. ${ }^{21}$ Thus the punitive damages defendant has virtually the same opportunity for confrontation as the criminal defendant. ${ }^{22}$

The punitive damages defendant, moreover, already enjoys the criminal defendant's right to compulsory process for obtaining favorable witnesses, ${ }^{23}$ through the subpoena power of the civil courts.24

\section{Double Jeopardy}

Since many torts which give rise to liability for punitive damages are also crimes, ${ }^{25}$ defendants may be exposed to both criminal and civil penalties for the same conduct in contravention of the spirit, though not the letter, ${ }^{26}$ of the fifth amendment's prohibition of double jeop-

892 (Fla. 1953); Ralph v. State, 124 Ga. 81, 52 S.E. 298 (1905); People v. Werblow, 128 Misc. 204, 205 N.Y.S. 617 (Sup. Ct. 1924); State v. Browning, 98 Ohio App. 8, 128 N.E.2d 173 (1954).

10 See generally 26 A C.J.S. Depositions § 68 (1956).

20 Where a party takes a deposition on written interrogatories, some courts say "fair play" requires the adverse party to cross-examine only by writings as well. English v. Gordon, 231 Ill. App. 316 (1924) (dictum); Shepard v. Missouri Pac. Ry., 85 Mo. 629 (1885); United States Cas. Co. v. Leahy, 54 Ohio Op. 418, 122 N.E.2d 310 (C.P. 1954); Neeves v. Gregory, 86 Wis. 319, 56 N.W. 909 (1893).

21 Authorities cited note 20 supra. Of course, the witness who ultimately testifies directly in court is always subject to cross-examination. Hartzell v. United States, 72 F.2d 569 (8th Cir.), cert. denied, 293 U.S. 621 (1934); Yadkin Valley Motor Co. v. Home Ins. Co., 220 N.C. 168, 16 S.E.2d 847 (1941); Rich Hill Coal Co. v. Bashore, 334 Pa. 449, 7 A.2d 302 (1939).

22 Of course, cross-examination in the court room may more effectively impeach a witness than a written record. However, this advantage seems expendable compared to the speed, efficiency, and necessity which motivate legislatures and courts to permit the taking of out-of-court testimony. Cf. Ahern v. Superior Court, 112 Cal. App. 2d 27, 245 P.2d 568 (1952).

23 U.S. CoNsT. amend. VI: "In all criminal prosecutions, the accused shall enjoy the right . . . to have compulsory process for obtaining witnesses in his favor . . . ." State provisions are similar. E.g., FLA. CONST. Declaration of Rights § 11; Mich. ConsT. art. I, $\S 20$.

24 Civil courts are said to have an inherent power to subpoena witnesses, and under the common law generally the subpoena ad testificandum is regarded as a matter of right. See, e.g., Trombetta v. Amringe, 156 Misc. 307, 310, 280 N.Y.S. 480, 483-84 (Sup. Ct. 1935).

25 E.g., assault and battery, Shelley v. Clark, 267 Ala. 621, 103 So. $2 d 743$ (1958); trespass, Shevlin-Carpenter Co. v. Minnesota, 218 U.S. 57 (1910); Cosgriff Bros. v. Miller, 10 Wyo. 190, 68 Pac. 206 (1902); personal injuries caused by reckless driving, Brooks $v$. Wooton, 355 F.2d 177 (2d Cir. 1966); Miller v. Blanton, 213 Ark. 246, 210 S.W.2d 293 (1948); seduction, Luther v. Shaw, 157 Wis. 234, 147 N.W. 18 (1914); bigamy, Morris v. MacNab, 25 N.J. 27I, 135 A.2d 657 (1957); conversion, Klam v. Koppel, 63 Idaho 171, 118 P.2d 729 (1941).

26 Read literally, the double jeopardy clause of the fifth amendment, and similar state provisions, apply only to an "offense," which in the context of that amendment 
ardy. ${ }^{27}$ Courts in a few jurisdictions, notably Indiana, have resolved this seeming injustice by refusing to allow exemplary damages where the defendant is also subject to criminal prosecution. ${ }^{28}$ Generally, however, recovery of punitive damages is not precluded by the possibility of criminal punishment. ${ }^{29}$ The majority takes the position that ex-

refers solely to criminal offenses. See Ex parte Lange, 85 U.S. (18 Wall.) 163 (1874); United States v. Bullinger, 290 Fed. 395 (1923); Commonwealth ex rel. Garland v. Ashe, 344 Pa. 407, 26 A.2d 190 (1942). Some critics argue that all constitutional protections for the criminal defendant are constitutionally required for the punitive damages defendant, because these damages are penal in nature. See, e.g., Orkin Exterminating Co. v. Truly Nolen, Inc., 117 So. 2d 419, 422-23 (Fla. Ct. App.), cert. denied, 120 So. 2d 619 (Fla. 1960); Aldridge, The Indiana Doctrine of Exemplary Damages and Double Jeopardy, 20 IND. L.J. 123 (1945). This argument overlooks the literal language of the provisions which limits such safeguards to criminal prosecutions. See, e.g., U.S. Const. amend. VI; Hale v. Henkel, 201 U.S. 43 (1906) (privilege against self-incrimination); United States v. Zucker, 161 U.S. 475 (1896) (right to confront adverse witnesses).

Occasionally, however, these protections have been applied to quasi-criminal actions. See, e.g., Trop v. Dulles, 356 U.S. 86 (1958), discussed in note 5 supra. Most advocates of criminal safeguards for punitive damages do not claim a constitutional mandate, however. Rather, they note the similarity between the civil and criminal punishments and suggest the punitive damages defendant is equally deserving of protection. See, e.g., Murphy v. Hobbs, 7 Colo. 541, 5 Pac. 119 (1884) (right to confront adverse witnesses, double jeopardy); Taber v. Hutson, 5 Ind. 322 (1854) (double jeopardy). As discussed above, the identity of the two types of punishment is illusory, but the question remains whether the policies underlying the special criminal rights suggest similar safeguards are appropriate for the punitive damages defendant.

27 Murphy v. Hobbs, 7 Colo. 541, 5 Pac. 119 (1884); Fay v. Parker, 53 N.H. 342 (1873). "Double jeopardy" can also occur in normal civil procedure. Whereas under criminal trial rules, no appeal may be taken from an acquittal of the criminal defendant, in civil proceedings a decision favorable to the defendant may be appealed by the plaintiff. Thus, a civil defendant "acquitted" of liability for punitive damages may find his good fortune reversed on appeal. Cf. Comment, The Coercive Function of Civil Contempt, 33 U. CHI. L. REv. 120, 122 (1965).

28 These courts do not always make express reference to the double jeopardy clause, but it is clear from their decisions that they have its mandate in mind. See, e.g., Louisville, N.A. \& C. Ry. v. Wolfe, 128 Ind. 347, 27 N.E. 606 (1891); Fay v. Parker, 53 N.H. 342 (1873).

Other courts are quite explicit in drawing on the constitutional rule. E.g., Murphy v. Hobbs, 7 Colo. 541, 543, 5 Pac. 119, 120 (1884): "Perhaps the most impressive objection to allowing damages as a punishment .... is that which relates to dual prosecutions for a single tort. Our state constitution declares that no one shall be twice put in jeopardy for the same offense. ... What difference does it make to the accused ... that one prosecution takes the form of a civil action. . . . He is practically harassed with two prosecutions ... ." See also Cherry v. McCall, 23 Ga. 193 (1857); Taber v. Hutson, 5 Ind. 322 (1854). For some of the problems generated by the attempt to avoid punitive damages double jeopardy, see Aldridge, supra note 26. Aldridge places the foundation of the Indiana approach on the double jeopardy clause of the Indiana constitution-thus raising the Indiana doctrine to a constitutional requirement, not a mere matter of following "the spirit" of the constitution. Id. at 135-36.

29 See, e.g., Moore v. Illinois, 55 U.S. (14 How.) 13 (1852); State v. Shevlin-Carpenter Co., 99 Minn. 158, 108 N.W. 935 (1906), aff'd, 218 U.S. 57 (1910); Goldsmith's Adm'r v. Joy, 61 Vt. 488, 17 Atl. 1010 (1899); Luther v. Shaw, 157 Wis. 234, 147 N.W. 18 (1914). 
emplary damages awarded to a private party are not a substitute for criminal sanctions and have no necessary relationship to the penalty incurred for the public wrong. ${ }^{30}$

Neither the majority nor the minority view seems wholly satisfactory. The majority view suffers from the obvious injustice that a man may be overpunished for the same conduct even though neither judgment is excessive alone. The minority view ignores the social judgment that one kind of conduct may be both a public and a private wrong and that a single punishment may not be sufficient to punish and deter. As a New Jersey court noted: "[T] he inclusion of punitive damages in the plaintiff's tort judgment ... may effectively supplement the criminal law in punishing the defendant."31

A better approach to the punitive damages "double jeopardy" problem may be a procedure which permits double punishment, but only when the first penalty is not sufficient to achieve the goals of punishment. ${ }^{32}$ Professor Clarence Morris, an advocate of this "supplemental" approach, has observed that:

If the criminal courts punish all criminals effectively, a further admonition in civil courts cannot be useful in itself. The only excuse for invading a culprit's economic resources is to discourage such conduct as that in which he has indulged; and if he has been sufficiently admonished elsewhere, this reason disappears. ${ }^{33}$

Professor Morris suggests that because fixed criminal penalties cannot be tailored to the particular culprit, allowance for punitive damages may individualize punishment and thus "remedy some maladjustment not adequately treated by the criminal law." 34

As Professor Morris notes, ${ }^{35}$ a supplemental theory entails reciprocal adjustment of the civil and criminal penalties. Thus, the jury should know the extent to which the defendant has been punished criminally so as to adjust the civil admonition accordingly. The danger that the jury might misuse such information, causing it to assume liability or

30 See, e.g., Cosgriff Bros. v. Miller, 10 Wyo. 190, 236-37, 68 Pac. 206, 216-17 (1902); MCCORMICK, DAMAGES $\S 82$ (1935).

31 Morris v. MacNab, 25 N.J. 271, 281, 135 A.2d 657, 663 (1957). The court upheld $\$ 7,900$ in compensatory and $\$ 1,600$ in punitive damages for defendant's fraudulently inducing plaintiff to enter into a bigamous marriage and advance moneys to defendant. Prior to the civil judgment, the defendant had been convicted of bigamy, receiving a suspended sentence.

32 Note, supra note 1, $70 \mathrm{HARV}$. L. REv. at 524.

33 Morris, supra note 2, at 1195.

34 Id. at 1196.

35 Id. at 1197. 
assess heavier damages, ${ }^{30}$ could be minimized by separating the determination of liability from the determination of damages. ${ }^{37}$ If the civil trial precedes the criminal prosecution:

It would seem that the jury should assess damages without regard to the possibility of punishment in a criminal court, and if a criminal action is brought the adjustment should be made there. The judge of the criminal court can make such adjustments easily; he is unembarrassed by the reparative function, and may even . . . suspend sentences . . . . ${ }^{38}$

The major drawback of the mitigation approach is the difficulty of judging whether the civil and criminal penalties together are appropriately punitive or excessive. Professor Morris offers one possible guideline: the total amount should be sufficient to deter that form of conduct. ${ }^{39}$ In his view the probable result of a particular form of conduct is more important in determining the proper punishment than is the actual result in a particular case, since it is "the known tendency of acts which makes it desirable to prevent them, regardless of the particular results of any one commission." 40

Professor Morris' suggestions seem worthwhile as a means of carrying out the spirit of the prohibition of double jeopardy. They have some support in experience; several courts have permitted punitive damages defendants to show in mitigation that they have been criminally penalized for the same wrong. ${ }^{41}$ Courts have also stated that judges in crim-

36 Ibid.

37 At first glance, such separation may seem unworkable; the measure of punitive damages is essentially the outrageousness of the very conduct being proved to determine liability. However, certain information, such as the defendant's financial condition and past criminal conviction for the conduct under consideration, is relevant only to punishment and can be withheld until liability has been determined. The overlap between the facts measuring the punitive damages and those proving liability makes special trial of these aspects unnecessary at the "sentencing" stage, thus minimizing the time required for separate determinations of liability and punishment.

38 Morris, supra note 2, at 1197. Professor Morris suggests that since adjustments can more easily be made in the criminal courts, "it might be wise to allow continuance of the criminal trial until after the civil trial is terminated." Ibid.

$39 \mathrm{Id}$. at 1181.

40 Ibid. Morris' formula is only partially helpful in overcoming the difficulty of judging whether the two penalties are appropriate. It enables the jury to judge the individual defendant's acts more meaningfully, but sheds little light on the general deterrent aspect of setting punitive damages. The jury lacks the experience and information to measure what punishment is sufficient to deter all members of society from the specific conduct.

41 Saunders v. Gilbert, 156 N.C. 463, 476, 72 S.E. 610, 615 (1911); Smithwick v. Ward, 52 N.C. 64 (1859); Wirsing v. Smith, 222 Pa. 8, 70 Atl. 906 (1908); Jackson v. Wells, 13 Tex. Civ. App. 275, 35 S.W. 528 (1896). 
inal cases should take liability for punitive damages into account in assessing the criminal penalty. ${ }^{42}$ The mitigation approach does not fully satisfy the double jeopardy principle, which seeks to avoid not only excessive punishment ${ }^{43}$ but also the inhumanity of putting a man twice in fear of punishment, even though a guilty man is mistakenly acquitted in the first trial.44 The mitigation approach still leaves the defendant faced with two proceedings. However, a punitive damages action does not evoke the same anxieties which attend the prospect of a second criminal trial. Perhaps the less oppressive nature of punitive damages would justify leaving the defendant to face multiple trials, particularly when the mitigation approach relieves some of the potential harshness of punitive damages. As the foregoing discussion indicates, the lack of a double jeopardy safeguard for the punitive damages defendant may in some sense be inconsistent with the nature of punitive damages, but as will appear below, it is one of only a handful of safeguards whose absence appears to be unwarranted.

\section{Proof Beyond a Reasonable Doubt}

One of the most significant distinctions between civil and criminal determinations is the evidentiary rule governing the burden of persuasion (burden of proof). In civil cases the plaintiff must generally prove his case by "a preponderance of the evidence," 45 while in criminal cases the guilt of the defendant must be established "beyond a reasonable doubt." 46 As with other criminal safeguards, the criminal evidentiary rule is a response to the penal consequences of criminal liability:

Judges and jurors alike must be "satisfied" of the truth of all allegations or denials of fact. What amounts to "satisfaction" will vary with the issues involved. The more trivial the question, the more easily and swiftly will "satisfaction" materialize. The more momentous and serious its consequences, the greater the caution and deliberation demanded, that is, the greater the amount of cogent evidence before there can be any "satisfaction" about where the truth lies. ${ }^{47}$

If one accepts the proposition that the consequences of punitive dam-

42 Keller v. Taylor, 7 Del. (2 Houst.) 20 (1858); Cook v. Ellis, 6 Hill (N.Y.) 466 (1844).

43 Cf. Ex parte Lange, 85 U.S. (18 Wall.) 163 (1874); Tesciona v. Hunter, 151 F.2d 589 (10th Gir. 1945).

24 Green v. United States, 355 U.S. 184 (1957); Bizzell v. State, 71 So. $2 d 735$ (Fla. 1954).

45 Magutre, Weinstein, Chadbourn \& Mansfieid, Cases on Evidence 694 (5th ed. 1965); MCCORMICK, EVIDENCE § 319 (1954).

46 MCCORMICR, EVDENCE § 321 (1954).

47 Fridman, Standards of Proof, 33 CaN. B. Rev. 665, 670 (1955). 
ages can be "momentous and serious," then justice requires increasing the burden of persuasion of the plaintiff in a punitive damages action. It is significant that in other kinds of civil action, courts have increased the plaintiff's burden of persuasion as the possible consequences to the defendant increase. ${ }^{48}$

\section{Trial By Jury}

Not every punitive damages defendant is assured the right to trial by jury. Although the great bulk of punitive damages cases are tried at law and are therefore under the protection of the right to jury trial, ${ }^{49}$ some punitive damages defendants face possible loss of their right to jury trials in such major jurisdictions as California and New York, where punitive damages may be awarded by courts sitting in equity. ${ }^{50}$ In most jurisdictions, however, courts have forbidden equity

48 This higher standard is described by phrases such as "by clear and convincing evidence," Lynch v. Lichtenthaler, 85 Cal. App. 2d 437, 441, 193 P.2d 77, 80 (1948) (agreement for reciprocal wills), and "clear, unequivocal, satisfactory and convincing," Capps v. Capps, 110 Utah 468, 475, 175 P.2d 470, 473 (1946) (oral trust). The types of cases to which this burden is applied include overcoming a statutory presumption that a member of a car owner's family was driving it with his consent, Krisher v. Duff, 331 Mich. 699, 50 N.W.2d 332 (1951), or proving, in a will contest, no undue influence where a beneficiary occupies a fiduciary capacity and natural objects of bounty are excluded, Berkowitz v. Berkowitz, 147 Conn. 474, 162 A.2d 709, 710 (1960). See generally McCormrck, EvidENCE § 320 (1954); Morse, Evidentiary Lexicology, 59 Drck. L. REv. 86 (1954).

49 The right to trial by jury in civil actions at law is secured by the seventh amendment of the federal Constitution and similar state provisions. See note 55 infra and accompanying text. However, these state and federal guarantees apply solely to actions at law; the right does not extend to proceedings in equity. See note 60 infra.

50 There is no right to trial by jury in equitable actions, United States v. State of Louisiana, 339 U.S. 699 (1950); Barton v. Barbour, 104 U.S. 126 (1881); Wirtz v. Norton, 34 F.R.D. 535 (D.C. Ga. 1963); Waggoner v. Johnston, 408 P.2d 761 (Okla. 1965), even though the distinction between law and equity has lost its previous vitality. Innersprings, Inc. v. Joseph Aronauer, Inc., 27 F.R.D. 32 (E.D.N.Y. 1961). In an equitable proceeding, however, the judge usually may, in his discretion, submit particular issues to a jury for an advisory verdict. Van Hecke, Trial by Jury in Equity Cases, 31 N.C.L. REv. 157 (1953). Such an advisory jury does not satisfy the constitutional guarantee of trial by jury, which demands a binding verdict outside the discretion of the judge and which can only be set aside for cause. See Van Hecke, supra at 158 n.5. Thirteen states have experimented with a right to trial by jury in equity cases, with a binding verdict as at law, of which four today widely use the non-discretionary, binding jury in equity: Georgia (for over 170 years), Texas (over 117 years), Tennessee (over 114 years), and North Carolina (over 89 years). Van Hecke, supra at 158-73. Thus the right to jury trial in these four states is satisfied with respect to equity proceedings. (Throughout the remainder of this comment, it is assumed that the above four jurisdictions are excepted when reference is made to the absence of a right to jury trial in equity.)

Two examples illustrate the important kinds of cases which involve punitive damages and which are tried in equity without juries. In Sandler v. Gordon, 94 Cal. App. 2d 254, 210 P.2d 314 (1949), the plaintiff merchant sued for recovery of damages and for injunction against defendant's solicitation and servicing of plaintiff's customers. The 
awards of punitive damages. ${ }^{51}$ Their decisions reflect in part the notion that punishment is outside the power of equity and are not expressly grounded on absence of a right to jury trial. ${ }^{52}$ This latter consideration, however, appears to underlie many of the cases, ${ }^{53}$ and at least one

defendant had stolen plaintiff's customer lists and was furnishing services to these persons without charge for purposes of injuring plaintiff and destroying competition. The lower court issued the injunction and awarded $\$ 1,400$ actual damages and $\$ 500$ punitive damages. On appeal, the punitive damages award was upheld. In an Indiana case, Hedworth v. Chapman, 135 Ind. App. 129, 192 N.E.2d 649 (1963), the appeals court affirmed an equity award of punitive damages against the defendant in a cross complaint which charged misrepresentation of boundaries and sought reformation of the real estate contract plus damages, including exemplary damages. The trial court awarded $\$ 1,500$ punitive damages, in addition to $\$ 384$ actual damages.

Another example of the award of punitive damages by a court sitting in equity without a jury is I.H.P. Corp. v. 210 Central Park South Corp., 12 N.Y.2d 329, 189 N.E.2d 812 (1963) (action by lessee against lessors to restrain interference with lessee's use of the premises). The Court of Appeals upheld a punitive damages award, stating that since the merger of law and equity, the one court of general jurisdiction administers all New York law, both equitable and legal. The court acknowledged that "we are obliged to preserve inviolate "Trial by jury in all cases in which it has heretofore been guaranteed by constitutional provision' (N.Y. Const., art. I, § 2)." But the court indicated in dictum that this right does not apply where the underlying cause of action is an equitable one, and the legal issues are incidental to the equitable relief sought.

In at least Missouri and Montana, the question of punitive damages awards in equity has been raised but left unsettled. See Bellerive Country Club v. McVey, 365 Mo. 477 , 284 S.W.2d 492 (1955); Cirese v. Spitcaufsky, 265 S.W.2d 753 (Mo. Ct. App. 1954); State ex rel. Tillman v. District Court,. 101 Mont. 176, 53 P.2d 107 (1936).

In those courts which permit equity award of punitive damages, equity jurisdiction of the punitive damages claim usually arises under the "incidental issues" or "complete justice" doctrine: "It is familiar law that a litigant in equity may ask and receive damages or other relief normally awarded in a court of law. The chancellor was not deterred from adjudicating such 'legal' issues, for they were thought of as incidental and their disposition was necessary to the effective termination of the entire matter in dispute." Levin, Equitable Clean-Up and the Jury: A Suggested Orientation, 100 U. PA. L. Rev. 320 (1951).

51 Most courts which have considered equity award of punitive damages, including the federal courts, declare that a court of equity has no power to award exemplary damages, even where it has power to award compensatory damages. United States v. Bernard, 202 Fed. 728 (9th Cir. 1913); United States v. Hart, 86 F. Supp. 787 (E.D. Va. 1949); Superior Constr. Co. v. Elmo, 204 Md. 14, 16, 104 A.2d 581, 583, reversing on rehearing, 204 Md. 1, 102 A.2d 739 (1954); Mid-Continent Petroleum Corp. v. Bettis, 180 Okla. 193, 195, 69 P.2d 346, 348 (1937); I SEdgwick, MEAsure of Damages (9th ed. 1912). Cf. Elizabeth v. American Nicholson Paving Co., 97 U.S. 126 (1877).

52 Many of the courts which have rejected the award of punitive damages in equity have offered no explicit reason for their stance. Others assert that equity simply lacks the power. See authorities cited note 5I, supra. Still others rest on the doctrine that an award of punitive damages is incompatible with the principles of equity and that a plaintiff waives his claim to punitive damages by seeking equitable relief. See, e.g., Annot., 48 A.L.R.2d 947 (1956).

53 Orkin Exterminating Co. v. Truly Nolen, Inc., 117 So. 2d 419, 422 (Fla. Ct. App.), cert. denied, 120 So. $2 \mathrm{~d} 619$ (Fla. Sup. Ct. 1960); cf. Developments in the Law-Injunctions, 78 HaRv. L. REv. 994, 1004 (1965). 
court has expressly held that awards of punitive damages by a court sitting in equity cannot stand because the defendant is denied the right to jury trial. ${ }^{54}$ The question thus arises whether punitive damages defendants in those jurisdictions which allow equity awards of punitive damages should be guaranteed the right to jury trial and, if so, how this right should be implemented.

Most judicial discussions of the right to jury trial where it already exists-in civil actions at law $w^{55}$ and in criminal prosecutions ${ }^{56}$ - simply accept the right to jury trial as "a basic and fundamental feature of our system." "b7 A few courts have offered more probing analyses. From their decisions the following considerations emerge as underlying both the civil and criminal rights to trial by jury:

1. Addition of Community Knowledge and Sentiment. ${ }^{58}$ The need for the popular and nonprofessional perspective which the jury brings to the courtroom is particularly acute where punitive damages are involved, because it is upon contemporary community standards that conduct is judged as wanton, grossly negligent, outrageous, or malicious -and thus a proper basis for punitive damages. ${ }^{59}$ The jury is also said

Aside from the jury question, perhaps the most important reason for equity's refusal to award punitive damages is the nature of equity itself-historically it has refused to enforce punishment or vengeance. See Superior Constr. Co. v. Elmo, 204 Md. 14, 16, 104 A.2d 581, 583, reversing on rehearing, 204 Md. 1, 102 A.2d 739 (1954); 1 Pomeroy, EQUITY JURISPRUDENCE $\$ 381$ (1881).

54 Orkin Exterminating Co. v. Truly Nolen, Inc., 117 So.2d 419, 422 (Fla. Ct. App.), cert. denied, 120 So. 2d 619 (Fla. Sup. Ct. 1960).

The Oklahoma Supreme Court has also held that punitive damages may only be awarded by a court where the right to jury exists, Mid-Continent Petroleum Corp. v. Bettis, 180 Okla. 193, 195, 69 P.2d 346, 348 (1937), but the court cannot be said to have relied expressly on a constitutional right to jury trial. The holding is primarily a result of statutory construction.

55 U.S. CoNST. amend. VII: "In Suits at common law, where the value in controversy shall exceed twenty dollars, the right of trial by jury shall be preserved. . . A Although this applies only to trials in federal courts, Fay v. New York, 332 U.S. 261 (1947); Walker v. Sauvinet, 92 U.S. 90 (1875), state constitutions generally contain a similar guarantee. Joiner, Civil Justice and the Jury 58 (1962); see, e.g., MAss. Const. art. 15; PA. Const. art. $1, \S 9$.

56 The right to jury trial in criminal actions is expressly secured by the federal Con. stitution and similar state provisions. U.S. ConsT. art. III, \& 2 provides: "The Trial of all Crimes . . . shall be by Jury . . . ." The sixth amendment states: "In all criminal prosecutions, the accused shall enjoy the right to a speedy and public trial, by an impartial jury ...." A typical state provision is PA. Const. art. $1, \S 9$.

57 Bailey v. Central Vt. Ry., 319 U.S. 350, 354 (1943).

58 Smith v. Times Publishing Co., $178 \mathrm{~Pa}$. 481, 500, 36 Atl. 296, 297 (1897). See also Wyzanski, A Trial Judge's Freedom and Responsibility, 65 HARv. L. Rev. 1281, 1287-88 (1952).

59 Clark v. McClurg, 215 Cal. 279, 9 P.2d 505 (1932) (oppression); Harrington v. Hadden, 69 Idaho 22, 202 P.2d 236 (1949) (outrageousness); Sinclair Refining Co. v. McCullom, 107 Ind. App. 356, 24 N.E.2d 784 (1940) (gross negligence); Ashland Dry 
to be particularly suited for setting the penalty for such conduct: "[T]he amount awarded is limited by the common conscience which is called into play by the jury system."60

2. Protection against Arbitrary and Secret Tribunals. ${ }^{61}$ This reason for jury participation is not relevant to the equity punitive damages defendant in contemporary courts, largely because secret and irresponsible tribunals are no longer considered a threat to our legal system. Furthermore, in the punitive damages situation, the plaintiff is generally a private party, so that there is no overlap between public prosecutor and public fact finder.

3. Citizenship Training. ${ }^{62}$ Here again there is no impetus for extending jury protection to the equity punitive damages defendant. While there may be some merit to the contention that jury duty contributes to a healthy democracy, democracy will not falter if a jury does not participate in every proceeding.

4. Twelve Heads Are Better than One. A vital concept underlying the right to jury trial is the belief that twelve men are more likely than one to make a correct determination of contested factual issues. ${ }^{63}$ The consequences of criminal conviction are in part what determine when the right to jury trial attaches in criminal prosecutions; ${ }^{64}$ thus it may be helpful, in determining whether the right to jury trial should apply to equity punitive damages defendants, to ask whether the consequences of injustice to the punitive damages defendant are the same as the consequences for the criminal defendant. As seen earlier, ${ }^{65}$ puni-

Goods Co. v. Wages, 302 Ky. 577, 195 S.W.2d 312 (1946) (wantonness); Zumwalt v. Utilities Ins. Co., 360 Mo. 362, 228 S.W.2d 750 (1950) (maliciousness); Morris v. McNab, 25 N.J. 271, 135 A.2d 657 (1957) (fraud). See generally 22 AM. Jur. 20 Damages \$ 249 (1965).

60 Orkin Exterminating Co. v. Truly Nolen, Inc., 117 So. $2 d$ 419, 423 (Fla. Ct. App.), cert. denied, 120 So. $2 \mathrm{~d} 619$ (Fla. Sup. Ct. 1960); cf. Wyzanski, supra note 58, at 1287-88. But see Frank, Courts on Trial 137-38 (1949).

61 See Flint River Steamboat Co. v. Foster, 5 Ga. 194, 206-07 (1848); Smith v. Times Publishing Co., $178 \mathrm{~Pa} .481,506,36$ Atl. 296, 308 (1897). Apparently the fear of sovereign power as exercised through the courts was a chief motive in the jury guarantees of the Constitution (and state constitutions). The jury was seen as an assurance that man's fate would be in the hands of his neighbors, not those of the government. Warren, New Light on the History of the Federal Judiciary Act of 1789, 37 HARV. L. REV. 49, 78-79 (1923).

62 See, e.g., Flint River Steamboat Co. v. Foster, 5 Ga. 194, 206 (1848); JoINER, op. cit. supra note 55 , at 66-67.

63 See Bailey v. Central Vt. Ry., 319 U.S. 350, 353 (1943); District of Columbia v. Clawans, 300 U.S. 617, 634 (1937) (McReynolds, J., dissenting); Flint River Steamboat Co. v. Foster, 5 Ga. 194, 206 (1848).

64 Schick v. United States, 195 U.S. 65, 68 (1904); Flint River Steamboat Co. v. Foster, 5 Ga. 194, 206 (1848); cf. Developments in the Law-Injunctions, 78 HARv. L. REv. 994, 1089 (1965).

65 See notes 8-15 supra and accompanying text. 
tive damages do not carry the consequences which motivate the special concern that the criminal defendant be tried by a jury. On the other hand, the economic perils faced by the punitive damages defendant can be severe. The protection of twelve heads seems advisable, particularly inasmuch as such protection is provided in most actions for ordinary damages. ${ }^{66}$ The cost to the system of adding this protection for this small class of defendants-those in actions in equity where there is a claim for punitive damages-does not seem particularly large. ${ }^{67}$

The foregoing analysis of the reasons underlying jury trial indicates

66 Insofar as the equity punitive damages defendant is denied a jury, he is denied the benefits of collective determination. See Orkin Exterminating Co. v. Truly Nolen, Inc., 117 So. 2d 419, 423 (Fla. Ct. App.), cert. denied, 120 So. 2d 619 (Fla. Sup. Ct. 1960): "It is not intimated that a chancellor has less of this inherent sense of justice, but his judgment is the judgment of one man and that of the jury is the judgment of many."

A jury, of course, is not the sole means of assuring determination by more than one man. Panels of judges or commissioners could be used. However, the expense of additional professional factfinders would probably be quite large (jury pay is relatively nominal), and use of such factfinders would destroy the advantages of lay participation. See JOINER, op. cit. supra note 55, at 73-74.

Naturally, not every equity punitive damages award will be so harsh as to merit the right to jury trial. But, since it is impossible to predict the size of the award in advance, efficiency argues that the right be available in every case-otherwise the chancellor might try the case without a jury, and another full trial, before a jury, could be required if it were held on appeal that the penalty was too severe and a jury should have been used. Furthermore, to the extent that severity is a question of communal standards, punitive damages are better determined by a cross-section of that community, the jury, than by the judge alone.

67 Courts or legislatures will be reluctant to assure a jury for equity punitive damages defendants if the cost-in time and money-exceeds the benefits to defendants. $C f$. Flint River Steamboat Co. v. Foster, 5 Ga. 194, 207 (1848); JoIner, op. cit. supra note 55, at 60-61. According to the best studies available, trial by jury is $67 \%$ longer than trial by the court alone. ZEIser, Kalven \& BuchHolz, DeLAy IN THE Court (1959), abstracted in JOINER, op. cit. supra note 55, at 222-33. The authors of this same study, however, interpret this figure as a worthwhile "price tag" for the jury system and futher note the possibility of speeding up the jury trial. $I d$. at 223. Moreover, jury trial may be faster than bench trial, since in bench trials continuances and other factors can delay the final judgment; in jury trials, "once a jury is impaneled the trial goes quickly to completion ... since the twelve jurors cannot be made to interrupt their normal lives for the length of time that a trial with continuances would take." $I d$. at 71-72. Use of a jury also has its monetary consequences: the government must pay jurors for their services; witnesses and litigants spend more time away from their jobs; and attorneys' fees mount as courtroom hours multiply. Yet, bench trials have their costs as well, for appeals from them are filed almost as a matter of course. Id. at 74. In any event, this "price" does not seem to warrant compromising protection for the equity punitive damages defendant, in light of the reasons for jury trial described above. Cf. Galloway v. United States, 319 U.S. 372, 406 (1943) (Black, J., dissenting); Schick v. United States, 195 U.S. 65, 99 (1904) (Harlan, J., dissenting); Levin supra note 50, at 325: "Various factors have played their part in accentuating the significance of the jury as a desirable political institution, for which sacrifice of 'efficiency' is a price worth while." But cf. Frank, Courxs on Trial 108-25 (1950); Gruswold, [1962-1963] HaRvard LAw School DeAN's Report 5; James, Trial by Jury and the New Federal Rules of Procedure, 45 YALE L.J. 1022, 1026 (1936); Levin, supra note 50 , at 325 . 
that the right might properly be applied to the equity punitive damages defendant. This right may be implemented in any of three ways: 1) separate trial of the punitive damages issues in a proceeding at law; 2) concurrent trial of the legal and equitable issues, with the jury passing on the legal issues and the court deciding equitable ones; or 3) provision for jury trial in all equitable proceedings, as in Georgia, North Carolina, Tennessee, and Texas. ${ }^{68}$

The first method, separate trials, is suggested by the federal constitutional doctrine for assuring jury determination of matters of legal fact in cases where equitable issues are also present. In Beacon Theatres $v$. Westover, ${ }^{69}$ and Dairy Queen v. Wood, ${ }^{70}$ the Supreme Court made it clear that when both legal and equitable issues are presented in the same case, "any legal issues for which a trial by jury is timely and properly demanded [must] be submitted to a jury"71 before determination of the remaining equitable aspects. Although binding only on the federal courts, Beacon and Dairy Queen may guide courts in states having comparable constitutional or statutory provisions..$^{72}$ How-

68 See note 50 supra.

69359 U.S. 500 (1959).

70369 U.S. 469 (1962).

$71 \mathrm{Id}$. at 473.

72 Of the five jurisdictions (California, Indiana, Missouri, Montana, and New York) where courts have upheld equity punitive damages or discussed the question and left it unsettled, it appears that New York and California already have a requirement similar to Dairy Queen, that legal issues be tried to a jury, but none yet requires that trial of the legal issues precede the equitable determinations. The California law is set forth in Pacific W. Oil Co. v. Bern Oil Co., 13 Cal. 2d 60, 69, 87 P.2d 1045, 1049 (1939), and Thomson v. Thomson, 7 Cal. 2d 671, 62 P.2d 358 (1936). The New York position is stated in Vinlis Constr. Co. v. Roreck, 23 App. Div. 2d 895, 896, 260 N.Y.S.2d 245, 247-8 (Sup. Ct. 1965), and Di Menna v. Cooper \& Evans Co., 220 N.Y. 391, 396, 115 N.E. 993, 994 (1917). Thus, at least some groundwork has been laid for adoption of the Beacon and Dairy Queen rules.

There is some question whether a Beacon-Dairy Queen type procedure might itself violate the Constitution: is there a constitutional right in equity to trial without a jury-that is, to trial by the bench alone, as is traditional in equity (assisted, perhaps, by an advisory jury)? Eight courts have held that such a right exists. Michaelson $v$. United States ex rel. Chicago, St. P., M. \& O. Ry., 291 Fed. 940, 946 (7th Cir. 1923); Brown v. Kalamazoo Circuit Judge, 75 Mich. 274, 42 N.W. 827 (1889); Arnold v. Sinclair, 12 Mont. 248, 277, 29 Pac. 1124, 1133 (1892); Steiner v. Stein, 2 N.J. 367, 380, 66 A.2d 719, 725 (1949); Hammond v. Foreman, 4.3 S.C. 264, 21 S.E. 3, 4 (1895); State v. Nieuwenhuis, 49 S.D. 181, 207 N.W. 77 (1926); Campbell v. Gowans, 35 Utah 268, 288, 100 Pac. 397, 401 (1909). Seven courts, including the Supreme Court, have taken the position that no bar exists to trial by jury in equity. Dice v. Akron, C. \& Y.R.R., 342 U.S. 359, 363 (1952); Hurwitz v. Hurwitz, 136 F.2d 796, 798 (D.C. Cir. 1927); Brown v. Greer, 16 Ariz. 215, 220, 141 Pac. 841, 843 (1914); Hopkins v. Greensburg, Knightstown, and Clarksburg Turnpike Co., 46 Ind. 187, 194 (1874); Susquehanna S.S. Co. v. A. O. Andersen \& Co., 239 N.Y. 285, 295, 146 N.E. 381,385 (1925); White v. Morrow, 187 Okla. 72, 73, 100 P.2d 872, 873 (1940); Lipscomb's Adm'r v. Condon, 56 W. Va. 416, 443, 49 S.E. 392, 402 (1904). See generally Van Hecke, supra note 50, at 171-73. It has been suggested that 
ever, the Beacon-Dairy Queen procedure has a major drawback: it delays the equitable claim until common fact issues are determined by the jury. Thus, the plaintiff may find the statute of limitations has run by the time he initiates his new action, and the increase in total trial time may force the defendant into settlement in order to avoid additional attorney's fees involved in a second trial. ${ }^{73}$ The second method, concurrent trial of the issues, appears most advantageous, as it assures jury trial of the legal issues while avoiding the adverse side effects of separate actions and concentrates time and effort more efficiently. ${ }^{74}$ Adoption of the third method seems unlikely, inasmuch as the few other states which have chosen to follow the four states mentioned have since reverted to traditional procedures. ${ }^{75}$

Since it seems probable that not all equity punitive damages defendants are adversely affected by the lack of a jury trial, it may always be argued that securing the right to those affected would not be worth the effort of making the change. But insofar as punitive damages represent a moral judgment by the community and contain the potential for severe punishment, the considerations which militate in favor of the right in criminal prosecutions and in actions at law justify extending it to the punitive damages defendant; and, of course, where the defendant feels a jury will be of no advantage, he would remain free to waive his right and forward speedy determination of his cause.

\section{Unanimous Verdict}

The right to a unanimous verdict has been termed an "inescapable element of due process"76 and is protected in federal ${ }^{77}$ and most state ${ }^{78}$

those courts which assert there is a right to equity trial without a jury are perhaps overbound by tradition or by an uninformed fear of how a jury trial would work in equity cases. $I d$. at 173 . One commentator contends there is no clear constitutional right to trial by the court, and courts should not be reluctant to provide jury trial for all issues. Note, The Right to a Nonjury Trial, 74 Harv. L. REv. 1176 (1961). Another writer has observed that this problem is essentially one of policy for the courts to resolve in the absence of legislative action. Note, 15 ALA. L. REV. 562, 567 (1963). Interestingly, equity's traditional eschewal of trial by jury is a matter of historical accident: the practice of trial by the judge alone flows from the redress of grievances by the king's chancellor, after the types of writs at law were restricted, See JorNer, op. cit. supra note 55 , at $41-42$.

73 See Levin, supra note 50, at 324.

74 Cf. Vinlis Constr. Co. v. Roreck, 23 App. Div. 2d 895, 896, 260 N.Y.S.2d 245, 248 (Sup. Ct. 1965); Levin, supra note 50, at 345.

75 See Van Hecke, supra note 50, at 173.

76 Fibdon v. United States, 204 F.2d 834, 838 (6th Cir. 1953).

77 See Andres v. United States, 333 U.S. 740 (1948); Hibdon v. United States, 204 F.2d 834 (6th Cir. 1953). The right has been given statutory form in the federal courts. FED. R. CRIM. P. 31.

78 At least four states permit less than unanimous verdict: IDAHO CoNsr. art. 1, § 7; 
criminal prosecutions as an integral part of the defendant's right to jury trial. Civil defendants in federal courts also enjoy the right to a unanimous verdict under the seventh amendment; ${ }^{79}$ that amendment, however, has not been held applicable to the states, ${ }^{80}$ at least twentythree of which provide for less than unanimous verdicts in civil cases. ${ }^{81}$ Thus, in many jurisdictions, the punitive damages defendant may be subject to punishment without unanimity among his jurors. ${ }^{82}$

The purpose of the unanimity rule is to prevent mistakes by ensuring that the defendant will be convicted only when every juror is convinced of his guilt. ${ }^{83}$ Thus, like other criminal safeguards, the rule is a response to the severity of criminal punishment. ${ }^{84}$ It might be argued here, as elsewhere, that although punitive damages do not have the same consequences as criminal punishment, and the need for providing equivalent safeguards is therefore less urgent, ${ }^{85}$ the cost of providing the safeguard would be small in relation to the benefit to defendants who face potentially severe penalties. ${ }^{86}$

However, a strong case for the opposite conclusion might be made by challenging the unanimity rule itself. Proponents of the majority verdict point to the disparity between the origins of the unanimity rule and the jury's present function. The rule, it is said, originated as the measure of evidence deemed conclusive of a dispute, since jurors originally were actual witnesses. After this function of the juror changed, the requirement apparently remained as a protection against government tyranny. ${ }^{87}$ The need for this protection has also faded, and it is contended that the rule is incongruous, since unless men could reasonably differ as to the force of the evidence there would be no

IDAHo CodE ANN. § 19-2316 (1948) (misdemeanors only); LA. Const. art. 7, § 41 (offenses punishable by less than capital punishment); LA. REv. STAT. ANN. \$\$ 15: $337-338$ (1951); OrLA. Const. art. 2, § 19 (less than felonies); TEX. Const. art. 5, $\$ 13$ (less than felonies).

79 The seventh amendment, which governs civil actions, has been held to include a unanimous verdict rule within its right of trial by jury. American Publishing Co. v. Fisher, 166 U.S. 464 (1897).

80 Maxwell v. Dow, 176 U.S. 581 (1900); Walker v. Sauvinet, 92 U.S. 90 (1875).

81 See JoINER, op. cit. supra note 55, at 220-21; [1961-1962] Michigan Constitutional Convention, Comments to Michigan Constitution of 1963 (art. 1, \& 14), in Mrch. STAT. ANN. (1965).

82 E.g., Earl v. Times-Mirror Co., 185 Cal. 165, I96 Pac. 57 (1921).

83 Hibdon v. United States, 204 F.2d 834 (6th Cir. 1953).

84 Ibid.

85 This is particularly true in states also allowing majority criminal verdicts, since it would be impossible to contend that punitive damages are a worse punishment than some of those which the state already allows without unanimous consent.

86 See text accompanying notes 13-14 supra.

87 Thomas \& Thomas, Interpretive Commentary on Texas Constitution, in 2 VernoN's TeXas Construtution 192 (1955). 
question for the jury. ${ }^{88}$ The majority verdict, it is argued, has some significant advantages: it minimizes jury tampering by increasing the number of jurors necessary to force a hung jury; it fosters truer verdicts by reducing bargained compromises with tiny minorities; ${ }^{89}$ and it promotes efficiency by reducing the number of retrials.90

These arguments in favor of the majority verdict merit serious consideration. The primary value of unanimous assent is its assurance that conviction cannot occur without the agreement of every juror. Yet, as seen above, it does not follow that facts are so unequivocal that reasonable men cannot disagree on them, and allegedly unanimous consent may only be a wearied compromise. ${ }^{91}$ These shadows cast on the value of the unanimity rule suggest restraint in demanding its extension to yet another legal arena, punitive damages.

\section{Excessive Fines}

Although the eighth amendment's prohibition against excessive fines $^{92}$ is generally considered applicable only to criminal sanctions, ${ }^{93}$ the standards of excessiveness which have evolved from decisions under this amendment have some relevance for the punitive damages situation. Two broad tests have emerged. The first test, whether or not the

88 Ibid. But see Mathes, Jury Instructions and Forms for Criminal Cases, 27 F.R.D. 39, 102-03 (1961), for sample jury instructions which suggest unanimity is realistically possible: "[I]f much the greater number of you are for a conviction, each dissenting juror ought to consider whether a doubt in his or her own mind is a reasonable one, since it makes no effective impression upon the minds of so many equally honest, equally intelligent fellow jurors."

89 Thomas \& Thomas, supra note 87, at 192; [1961-1962] Michigan Constitutional Convention, supra note 81 . Britain is currently considering a criminal justice bill which would allow majority verdicts in criminal cases, because it is said organized criminals have the power to bribe or intimidate one or two members of many juries and thus block a verdict. Lewis, Britain Is Hardboiled About Crime, N.Y. Times, Sept. 18, 1966, § 4, p. E7, col. 1 .

90 Thomas \& Thomas, supra note 87, at 192-93; [1961-1962] Michigan Constitutional Convention, supra note 81. See also State v. Lewis, 129 La. 800, 804, 56 So. 893, 894 (1911) (the purpose of majority verdicts is to reduce expenses and facilitate and expedite the administration of justice).

91 There is, however, some danger that majority verdicts will eliminate compromise entirely. Where the requisite majority of jurors are in agreement from the moment the jury begins its deliberation, there will be no impetus for the jurors even to consider the minority's views. Deliberation will be at best superficial-and the verdict perhaps improper.

92 U.S. Const. amend. VIII: "Excessive bail shall not be required, nor excessive fines imposed ...." State provisions follow the federal model. E.g., WASH. Consr. art. 1, \& 14; WIs. Const. art. 1, § 6 ("Excessive bail shall not be required, nor shall excessive fines be imposed .....?.

03 See, e.g., Ex parte Watkins, 32 U.S. (7 Pet.) 568, 574 (1833) (eighth amendment refers to federal courts of criminal jurisdiction); Lapinski v. Copacino, 131 Conn. 119, 38 A.2d 592 (1944) (eighth amendment applied in quasi-penal civil action). 
penalty is proportionate to the offense, has been explained in the following terms:

The amount of the fine which the Legislature may properly impose depends largely on the object designed to be accomplished by the imposition of the fine, and the widest latitude is to be given to the discretion and judgment of the Legislature in determining the amount of the fine necessary to accomplish that object. ${ }^{94}$

Proportion is thus measured by the gravity of the conduct punished or the importance to society of deterring that type of conduct. ${ }^{95}$ The second test of excessiveness is the burden of the penalty on the defendant. In United States $v$. United Mine Workers of America, ${ }^{96}$ the Court in passing on a contempt award said:

[A] court which has returned a conviction for contempt must, in fixing the amount of a fine to be imposed as punishment or as a means of securing future compliance, consider the amount of defendant's financial resources and the consequent seriousness of the burden to that particular defendant..$^{97}$

The civil courts have developed standards similar to those used to determine excessiveness in criminal cases. Although the jury is often said to have more latitude in setting punitive damages than in assessing compensatory damages, ${ }^{98}$ limited judicial review of awards in civil

04 Lapinski v. Copacino, 131 Conn. 119, 182, 38 A.2d 592, 598 (1944). In Lapinski, a landlord was "fined" (by the imposition of statutorily set civil damages in an action by his tenant) for overcharging rent under wartime price controls. The defendant there paid $\$ 50$ for each of seven $\$ 3$ monthly overcharges.

95 Cf. Walsh v. Gurman, 132 Conn. 58, 65, 42 A.2d 362, 365 (1945), another rent control case, where the court discussed whether the alleged disproportion between the act and the penalty deprived the defendant of his property without due process of law: "[T] he test is the reasonableness of the method ... adopted .... In determining whether such penalties are so severe, oppressive, and unreasonable as to violate the due process clause, they should be tested not by comparison with the [rent] overcharges in particular instances but by the public interest in having the [rent] prices uniformly adhered to and the relation of the penalties to that object."

96330 U.S. $258\left(194^{7}\right)$.

97 Id. at 304.

88 See Scott v. Times-Mirror Co., 181 Cal. 345, 367, 184 Pac. 672, 682 (1919); Thomas v. Mickel, 214 Miss. 176, 58 So. $2 d 494$ (1952); McCormick, Damages § 77 (1935). Punitive damages may largely exceed compensatory damages. Gordon v. McLearn, 123 Ark. 496, 185 S.W. 803 (1916). In general, the award will be set aside only if it is grossly excessive or appears to be the result of passion, prejudice, improper sympathy, or other improprieties in the trial. United States Fidelity \& Guaranty Co. v. Millonas, 206 Ala. 147, 89 So. 732 (1921); State ex rel. Atchison, T. \& S. F. Ry. v. Ellison, 268 Mo. 225, 186 S.W. 1075 (1916); Pendleton v. Norfolk \& W. Ry., 82 W. Va. 270, 95 S.E. 941 (1918); Hall Oil Co. v. Barquin, 33 Wyo. 92, 237 Pac. 255 (1925). Since the amount of punitive dam- 
actions insures a measure of control over the amount of punitive damages. A complement to the eighth amendment proportionality test may be found in some courts' attempts to narrow the jury's discretion by requiring a "reasonable relationship" between actual and exemplary damages. ${ }^{99}$ Other courts define a "reasonable relationship" by stressing the disparity between the punitive award and the type of injury inflicted. ${ }^{100}$ It has been observed, however, that the "reasonable relationship" test fails to carry out the deterrent function of punitive damages, since it emphasizes the harm actually done rather than the social undesirability of the defendant's type of behavior..$^{101}$

The punitive damages defendant already enjoys protection comparable to that provided by the eighth amendment's burden test. In most jurisdictions, evidence of the defendant's financial condition is admissible on the issue of punitive damages and may be considered by the jury in determining the amount sufficient to punish that particular defendant. ${ }^{102}$

ages is left initially to the complete discretion of the jury, an award of punitive damages cannot be set aside as inadequate. Louisville \& N. R.R. v. Street, 164 Ala. 155, 51 So. 306 (1910).

99 Courts are increasingly exercising this freedom. See, e.g., State ex rel. Atchison, T. \& S. F. Ry. v. Ellison, 268 Mo. 225, 186 S.W. 1075 (1916); cf. Booth v. People's Fin. 8. Thrift Co., 124 Cal. App. 131, 144, 12 P.2d 50, 55 (1932) (court's power to set aside exemplary damages "is the same as ... in any case of excessive damages, even though it is true that a jury has somewhat wider discretion in awarding punitive, than in fixing compensatory damages"). Awards set aside under this rule have included \$100 actual with $\$ 14,900$ exemplary damages, Bangert v. Hubbard, 126 N.E.2d 778 (Ind. App. 1955), and $\$ 1,250$ actual with $\$ 25,000$ exemplary, Hall Oil Co. v. Barquin, 33 Wyo. 92, 237 Pac. 255 (1925).

100 See Brink v. Kennedy, 286 Ky. 566, 151 S.W.2d 58 (1941); State ex rel. St. Joseph Belt Ry. v. Shain, 341 Mo. 733, 108 S.W.2d 351 (1937).

101 Note, Exemplary Damages in the Law of Torts, 70 HARv. L. REv. 517, 531 (1957). A standard generally ignored in setting punitive damages is the statutory penalty for a parallel criminal offense. Although the statutory standard appears useful as society's evaluation of the gravity of the offense and the degree of punishment necessary for punishment and deterrence, the predetermined maxima and minima lack the complete flexibility which permits punitive damages to be tailored to the individual defendant. Moreover, as seen earlier, one function of punitive damages is to supplement, not replace, the available criminal sanctions. At least one court has suggested that statutes authorizing double or treble damages are in certain cases an indication of public policy as to the amount of punitive damages for cases not covered by the statutes. See Pendleton v. Norfolk \& W. Ry., 82 W. Va. 270, 278, 95 S.E. 941, 944 (1918). However, such statutory damages are not appropriate as a measure of punitive damages, because they are set more as an inducement to litigate than as deterrence for a particular offense.

102 Marriott v. Williams, 152 Cal. 705, 93 Pac. 875 (1908); Peters v. Lake, 66 Ill. 206 (1873) (if evidence submitted soon after injury); Utlaut v. Glick Real Estate Co., 246 S.W.2d 760 (Mo. 1952); Suzore v. Rutherford, 35 Tenn. App. 678, 251 S.W.2d 129 (1952). The minority is represented by Givens v. Berkley, 108 Ky. 236, 56 S.W. 158 (1900); Texas Public Util. Corp. v. Edwards, 99 S.W.2d 420 (Tex. Civ. App. 1936). 
Since the measure of punishment in criminal proceedings is commonly left to the judge, subject to boundaries set by statute, it is worth considering whether the determination of punitive damages might also be left to the judge. Punitive damages, however, have been regarded as an expression of community sentiment and therefore a matter for jury discretion. ${ }^{103}$ In punitive damages cases, the jury must be both legislature and judge. Yet abuse of the jury's discretion has been a target of punitive damages critics. Since judges have more experience by which to gauge the propriety of penalties, courts should perhaps have more freedom than they do to set aside or reduce the jury's determination of exemplary damages. ${ }^{104}$

\section{Right to Counsel}

The sixth amendment right to counsel ${ }^{105}$ protects the accused from conviction due to ignorance of his legal rights. ${ }^{106}$ The punitive damages defendant has no constitutional right to counsel, but it is well established that civil litigants are entitled to be represented and to appear by an attorney. ${ }^{107}$ While the punitive damages defendant does not enjoy the benefit of Gideon $v$. Wainwright, ${ }^{108}$ which assures counsel to the indigent criminal defendant, it is doubtful that lack of counsel is a problem in punitive damages cases. No plaintiff would knowingly sue an indigent for monetary damages, and it is unlikely that a defendant with money would fail to provide himself with a lawyer.

103 Full representation of the larger society is possible, of course, only if the twelve jurors are drawn from a cross section of the whole society. It is commonly acknowledged that today's jury panels are often lacking in minority group representation and in representation of the better educated classes. Holbrook, Composition of Juries as a Group, in JOINER, op. cit. supra note 55, at 195-200.

104 Note, supra note 101, 70 HARv. L. REv. at 530. Although the jury presently enjoys great freedom in the setting of punitive damages, it is still a question of law for the judge whether evidence has been offered sufficient to take the question of punitive damages to the jury. For example, the plaintiff must offer proof of malice or recklessness, or another of the bases necessary to the allowance of punitive damages. Thus, the judge exercises at least initial control over punitive damages awards. See Eshelman v. Rawalt, 298 Ill. 192, 199-200, 13I N.E. 675, 677-78 (1921).

105 U.S. CONST. amend. VI: "In all criminal prosecutions, the accused shall enjoy the right to ... have the Assistance of Counsel for his defense." State provisions follow suit. E.g., Mich. CoNsT. art. 1, § 20: "In every criminal prosecution, the accused shall have the right ... to have the assistance of counsel for his defense . . . ."

108 Johnson v. Zerbst, 304 U.S. 458 (1938); Powell v. Alabama, 287 U.S. 45 (1932).

107 Magerstadt v. La Forge, 303 S.W.2d 130 (Mo. 1957); Anderson v. Anderson, 198 S.C. 412, 18 S.E.2d 9 (1942). Every licensed attorney duly admitted to practice possesses a general license to appear in court for any suitors who may retain him. 7 C.J.S. Attorney \& Client $\$ 62$, at 845 (1955).

108372 U.S. 335 (1963). 


\section{Self-Incrimination}

No witness has a right to refuse to answer questions which lead solely to civil liability. ${ }^{109}$ Since the privilege against self-incrimination $^{110}$ protects only against revelations which would subject the answerer to criminal prosecution, ${ }^{111}$ the punitive damages defendant upon taking the stand now must answer all questions which can subject him to liability for punitive damages. Again, the penal nature of punitive damages has led some courts and commentators to question the lack of a privilege against "self-incrimination" for punitive damages defendants. ${ }^{112}$

Of the many policies which authorities ${ }^{113}$ have suggested as underlying the privilege against self-incrimination, several reflect a common fear of abuse of government power through the criminal process. For the delegates to the Constitutional Convention, the privilege may have meant no more than a prohibition against torture or other physical violence. ${ }^{114}$ Underlying the modern privilege is a concern for other forms of governmental intrusion, many of them more subtle. Thus, it has been said that the privilege prevents browbeating or bullying of witnesses by overly zealous prosecutors and policemen, ${ }^{115}$ and that it guards the individual's right of privacy by precluding unlimited questioning. ${ }^{116}$ The punitive damages defendant in a civil tort action does not appear to need the same protections against bullying and invasion of privacy; he need not fear that his adversary will extract a confession

109 Boston \& M. R.R. v. State, 75 N.H. 513, 77 Atl. 996 (1910); MCCoRMICK, Evidence § 128 (1954). However, the privilege does cover answers subjecting the witness to penalty or forfeiture. See ibid.

110 U.S. ConsT. amend. V: "No person . . . shall be compelled in any criminal case to be a witness against himself ...." Despite variance in language, all states provide a privilege against self-incrimination similar in effect to the federal provision. 8 WIGMORE, Evwonce § 2252, at 319-31 (McNaughton rev. 1961). In Malloy v. Hogan, 378 U.S. 1 (1963), the fifth amendment privilege was held applicable to the states via the fourteenth amendment.

111 E.g., Hale v. Henkel, 201 U.S. 43, 66-67 (1906).

112 E.g., F. Speidel Co. v. N. Barstow Co., 232 Fed. 617, 619 (D.C.R.I. 1916); Spokane Truck \& Dray Co. v. Hoefer, 2 Wash. 45, 52, 25 Pac. 1072, 1074 (1891); Ghiardi, Should Punitive Damages Be Abolished?-A Statement for the Affirmative, [1964-1965] ABA Section on Insurance, Negligence and Compensation law Proceedings 285.

113 For an excellent bibliography on the policies behind the privilege, see 8 WIGMORE, EvIDENCE $\S 2251$, at 297-310 (McNaughton rev. 1961).

114 See $i d$. $\$ 2250$, at $294 \mathrm{n}$. 15.

115 "When a legal right to an answer exists, one can expect the presiding official to allow the questioner wide latitude in his attempts to extract relevant information of any kind ...." Id. § 2251, at 315-16. See 63 A.B.A. REP. 570, 591 (1938).

116 See Miranda v. Arizona, 384 U.S. 436, 460 (1966); United States v. Grunervald, 233 F.2d 556, $581-82$ (2d Cir.) (Frank J., dissenting), rev'd, 353 U.S. 391 (1957); ChafeE, The Blessings of Liberty 190 (1956). 
from him in the stationhouse, or summon him to an inquisition conducted under broad investigatory powers. ${ }^{117}$

Two related policies which assure an equal contest between the individual and the state by 1) preserving the individual's right not to cooperate in his own prosecution ${ }^{118}$ and 2) protecting against governmental harassment through baseless prosecution or inquisitorial proceedings $\mathrm{s}^{110}$ - are similarly inapplicable to the punitive damages defendant. The state is usually not a party, ${ }^{120}$ and the presence or absence of the privilege would have little effect on a vindictive plaintiff bent on bringing suit. ${ }^{121}$

It is said the privilege assures civilized treatment of the defendant by preventing his being compelled to "dig his own grave."122 But when the state is not his adversary and the consequences are no longer death or imprisonment, the argument is less compelling. Virtually all litigants must choose at some point between taking the stand, at the price of undergoing cross-examination, and refusing to testify, thereby risking adverse inferences from the failure to speak out and consequent loss of the lawsuit on plaintiff's unrebutted testimony. ${ }^{123}$

117 In fact, witnesses in civil tort actions are rarely "browbeaten" in the infamous sense of that term. See Iluinors State Bar Assoc. Section on Insurance Law, Preparing and Trying Cases in ILLINoIs $\$ 568$ (1951).

118 Fortas, The Fifth Amendment: Nemo Tenetur Prodere Seipsum, 25 Cleveland B.A.J. 91, 98-99 (1954).

110 See New York Constitutional Convention Committee, Privilege Against Self-Incrimination, 9 Problems Relating to Judiclal Administration and Organization 920, 923 (1938).

120 In those actions where the government acts as civil plaintiff, the state lacks the power it can exercise in criminal matters-the power of police custody and imprisonment before trial.

121 Of course, the privilege cannot prevent the government from bringing prosecutions. But it is more restrained than a civil defendant, since proof of a crime more often relies on the testimony of the accused than does proof of a tort; whereas in civil actions the victim (plaintiff) is almost always present at the trial.

122 Griswold, The Fifth AMendment Today 7-8 (1955).

123 In criminal prosecutions, it is error for the court to comment adversely on a defendant's use of the privilege, Griffin v. California, 380 U.S. 611 (1965); United States v. Ward, 168 F.2d 226, 227-28 (3d Cir. 1948); People v. Wiggins, 231 Ill. App. 467, 481 (1923); People v. Arthurs, 8 App. Div. 2d 966, 967, 161 N.Y.S.2d 971, 972 (1957), and the jury is instructed not to indulge in unfavorable presumptions against the accused because he exercises the privilege. See People v. Kynette, 15 Cal. 2d 731, 104 P.2d 794 (1940), cert. denied, 312 U.S. 703 (1941). In civil actions, however, failure of the defendant to testify on his own behalf properly allows the jury to draw adverse inferences. See, e.g., Stillman Pond, Inc, v. Watson, 115 Cal. App. 2d 440, 444, 252 P.2d 717, 718 (1953). Were a privilege against "self-incrimination" extended to punitive damages defendants, it is probable that similar rules against adverse inference would be promulgated, but the danger remains that the jury will indulge in such presumptions, whether or not prompted 
Another group of policies said to underlie the privilege against selfincrimination stem from the notion that justice is best served by requiring a party to build his own case without relying on false testimony or the opposition's admissions. Thus it is said that the privilege, although making it harder to get information directly, promotes long term efficiency by forcing prosecutors to build a solid case from objective proofs. ${ }^{124}$ This argument again appears to have special relevance to criminal prosecutions, where there is a danger of conviction on the basis of untrue confessions or where an innocent but nervous defendant may accidentally inculpate himself. ${ }^{125}$ While there may be some risks of this kind in the punitive damages situation, they are less significant. ${ }^{126}$ Moreover, any possible advantage of the privilege to the punitive damages defendant may be outweighed by the disadvantages of adverse inferences. ${ }^{127}$

Another aspect of the policy concerning the reliability of the defendant's testimony is that the privilege is said to afford the defendant a way out of the trilemma of choosing among harmful testimony, perjury, or possible contempt proceedings for refusing to answer. ${ }^{128}$ To some, this protection has seemed desirable on humanitarian grounds; ${ }^{129}$ others, however, have seen it as a means of freeing courts from the burden of false testimony. ${ }^{130}$ In this aspect the privilege, like other exclusionary rules of evidence, has been criticized by those who argue that the value of any testimony outweighs the danger that judge or jury would fail to assign it proper weight. Again, the value of the privilege to the punitive damages defendant seems dubious in any event because his silence may cost him the case; the plaintiff is ordinarily available to put forth a prima facie case. As the burden of proof in a civil case is less stringent than in a criminal case, if the defendant fails to rebut

by counsel or court. Cf. United Elec. Workers v. General Elec. Co., 127 F. Supp. 934 (D.D.C. 1954).

124 Chafee, The Blessings of Liberty 186 (1956).

125 Wilson v. United States, 149 U.S. 60, 66 (1893).

126 The false-confession danger is lacking in punitive damages cases because there is no systematic "grilling" or other inquisitorial proceeding. The danger of nervous selfinculpation is also smaller because the "stakes" are not as high, and tension is therefore less.

127 See MCCoRMICK, EvwoENCE § 132 (1954); cf. Meltzer, Required Records, the McCarran Act, and the Privilege Against Self-Incrimination, 18 U. CHr. L. Rev. 687, 699 (1951). The danger of adverse inference is not itself a reason for denying the privilege to the punitive damages defendant, since the decision whether or not to risk inferences is more properly left to each defendant rather than to the fiat of the legal system.

128 Aiuppa v. United States, 201 F.2d 287, 300 (6th Cir. 1952) (Martin, J.); Meltzer, supra note 127 , at $692-93$.

129 Authorities cited note 128 supra.

130 Cf. Meltzer, supra note 127, at 692 . 
the plaintiff's testimony, the cost in terms of the adverse inference drawn from a failure to testify might well be greater than the risk of testifying. ${ }^{131}$

A final justification for the privilege against self-incrimination is that it helps to frustrate bad law. ${ }^{132}$ As with unpopular criminal provisions, judge-made tort law may lack the support of public opinion. The punitive damages defendant, however, need not rely upon the privilege to protect him; that function is better performed by the jury, whose essential function in punitive damages cases is to set the "sentence" as well as determine liability by translating public sentiment into monetary damages. ${ }^{133}$

To the extent that the privilege against self-incrimination protects the individual from excesses of government power, it has little relevance to the punitive damages defendant, and any advantages that might result from extending the privilege to him may be outweighed by the disadvantages of adverse inference. The uncertain value of the privilege, coupled with the legal system's basic goal of reaching truth through consideration of the maximum probative evidence, suggests that extension of the privilege to the punitive damages defendant may not be desirable.

\section{Evidence of Character and Wealth}

At least one aspect of criminal evidence law is already recognized in punitive damages litigation. This is the rule allowing evidence concerning character and wealth of the defendant. ${ }^{134}$ Such evidence, by the prevailing rule, may not be admitted in civil actions for compen-

131 Cf. 8 WigMore, Evidence $\$ 2251$, at $311 \mathrm{n} .3$ (MCNaughton rev. 1961). In actuality, the trilemma may be only theoretical: "[T] doubt that it is thought of by the average witness as soul-destroying experience." Id. at 317 .

132 This policy traces to colonial times, when prerogative courts of governor and council held roving interrogations with an eye toward summary justice or later jury trial. The privilege did have a function at the trial stage: since a defendant could avoid confession, the jury had increased freedom to find a man innocent of laws of which the community disapproved. See Pittman, The Colonial and Constitutional History of the Privilege Against Self-Incrimination in America, 21 VA. L. Rev. 763, 783-84 (1935).

133 Hart \& MrNaughton, Evidence and Inference in the Law, 87 DaEdalus 40, 50 (1958). Although provided a jury trial, the criminal accused still needs the privilege against self-incrimination for questioning before grand juxies or legislative bodies. Clapp, Privilege Against Self-Incrimination, 10 RuTGERs L. REv. 541, 542-43, 546-47 (1956).

134 E.g., United States v. United Mine Workers of America, 330 U.S. 258, 304 (1947) (wealth in criminal proceeding); Dunson v. State, 202 Ga. 515, 522, 43 S.E.2d 504, 508 (1947) (character in criminal proceeding); Nelson v. Halvorson, 117 Minn. 255, 258, 135 N.W. 818, 819 (1912) (wealth in punitive damages); Hess v. Marinari, 81 W. Va. 500, 505-07, 94 S.E. 968, 970-71 (1918) (character in punitive damages). 
satory damages only, ${ }^{135}$ as it is feared it would prejudice the jury without adding meaningfully to the information needed to reach a determination..$^{136}$ In a criminal case, however, such evidence is admissible for determining the defendant's intent and the punishment which fits a particular defendant; ${ }^{137}$ in an action for punitive damages the jury must also consider the defendant's malice and the amount of the penalty effective for the particular defendant. ${ }^{138}$ Thus, application of this criminal rule of evidence is a function of necessity rather than a calculated attempt to provide safeguards for punitive damages defendants. ${ }^{139}$

\section{ConcLusion}

The foregoing analysis of criminal-defendant safeguards suggests that the lack of such procedures is not, in general, inconsistent with the civil imposition of punitive damages.

In evaluating the appropriateness of such new protections, two tests have been applied: 1) The applicability of the policies underlying particular safeguards to the punitive damages situation, and 2) the impact of new procedures on judicial administration. Applying these tests, certain safeguards seem to be unwarranted for the punitive damages situation: the right to unanimous verdict; the privilege against self-incrimination; and the absolute protection against double jeopardy. For many of the safeguards, a counterpart in punitive damages actions was discovered; these include the rights to confront adverse witnesses, to compulsory process for favorable witnesses, to assistance of counsel, to protection against excessive fines, and to evidence on the defendant's character and wealth. A dominant policy behind the criminal safeguards has been protection against the particular oppression of criminal punishment. The consequences of punitive damages cannot be said to be equivalent, but their penal nature and frequently large magnitude suggest that certain safeguards should be accorded the punitive damages defendant; these include the right to trial by jury in all punitive damages cases and an increased burden of persuasion for the plaintiff.

135 Hess v. Marinari, 81 W. Va. 500, 506-07, 94 S.E. 968, $970-71$ (1918); 4 SUTHERLAND, DAMAGes § 1254, at 4778-80 (4th ed. 1916).

136 See Hess v. Marinari, 81 W. Va. 500, 94 S.E. 968 (1918) (by implication); Note, supra note 101, 70 HARV. L. REV. at 528.

137 See authorities cited note 134 supra.

138 See Hess v. Marinari, 81 W. Va. 500, 94 S.E. 968 (1918).

139 Despite the necessity for evidence as to character and wealth in punitive damages actions, the danger remains of prejudicing the jury on the issue of ordinary liability. To circumvent this problem, the jury could first reach a verdict on the compensatory damages and then hear evidence relating to the punitive damages claim. Note, supra note 101, 70 HARV. L. REV. at 528. 
Thus, allegations of asymmetry in the practice of allowing punitive damages without providing criminal safeguards are superficial in varying degrees. Some safeguards, although not compelled, might be appropriate; most are not, or are warranted only in modified form. The durability of the practice is due less to the law's tolerance of inconsistency than to an apparent recognition that, for the most part, the practice is not as anomalous as it first appears. 